\title{
"A Municipalização e a Enfermagem"
}

A Municipalização é o tema da atualidade. Foi e é talvez, a esperança daqueles que elaboraram a constituição brasileira de 1988. A intenção, à época, era legislar na perspectiva de bem atender ao cidadão em suas diversas necessidades, possibilitando-Ihe ainda, o controle social do poder local. Era a racionalidade política gerando a racionalização das ações dos poderes executivo e legislativo municipais.

Contudo, a idéia de gestões participativas, onde os munícipes poderiam intervir de maneira sistemática, desde a organização popular, nem sempre foi pautada como na década de 80 e atualmente. Frustrada, no passado não logrou o êxito esperado. Entre diversos fatores, situa-se o coronelismo, fortemente enraizado e atuante no interior, e influenciador de opiniões nos centros urbanos, inibindo ou alijando as formas de participação das coletividades nas decisões políticas em todos os níveis. Sem um sistema de comunicação eficiente, a informação não era instrumento de consumo da maioria da sociedade. Assim como cobrar os compromissos de governo e exercer o controle social? Estas atitudes se evidenciadas, eram restritas ao grupo partidário minoritário e oposicionista, às vezes acompanhado de significativas manifestações populares quanto às ações governamentais.

$\mathrm{Na}$ época da ditadura - centralizadora por princípio - o processo de municipalização foi reprimido. O poder atribuído ao nível local, sobretudo o financeiro, certamente enfraqueceria o processo de controle e de barganha, dificultando a consolidação de dependência dos municipios ao governo federal.

Todavia, avanços foram observados na valorização do poder municipal. Alguns fatores contribuíram, na década de 80 , para isto. 0 governo da ditadura militar, já em decadência, via na concentração de renda, autoritarismo político, censura da imprensa - a força impedindo a intervenção do povo. Errou ainda acreditando que o povo pudesse ser substituído por tecnocratas.

A organização da sociedade civil cresceu e conquistou avanços necessários ao desenvolvimento da politica de abertura que gradativamente se instalava no país. Muito embora as reformas administrativa e tributária não tenham ocorrido, as iniciativas de municipalização da saúde implementada em consonância com as propostas da Reforma Sanitária - viabilizadas pelo que tem sido possível organizar do Sistema Único de Saúde (SUS) - conseguem ser exitosas quando bem conduzidas.

Constatam-se progressos em muitos municipios. Conferências municipais de saúde são realizadas, Conselhos e Secretarias Municipais de Saúde se criaram ou se organizaram, e há exemplos de gestões financeiras participativas, onde os representantes dos usuários opinam e decidem sobre as propostas, e os gastos face à receita disponivel. Caminha-se para o sucesso da proposta de municipalização da saúde. 
Neste sentido, indaga-se se as escolas superiores de saúde estão capacitando profissionais para atuarem nos municipios afastados dos grandes centros urbanos, distanciados das super especializações, da alta tecnologia, dos recursos terapêuticos mais atualizados. Com tal capacitação tais profissionais estarão aptos a se contextualizarem, do ponto de vista sócio-político-econômicocultural, para exercerem a profissão de forma coerente e adequada às possibilidades locais, estando permanentemente reivindicando meios para qualificarem seus serviços e a sua atuação. Serão, ainda, perspicazes para lutarem por melhores condições de vida, quer ambientais, de segurança, de sobrevivência, interagindo com a população na luta por seus direitos de cidadania. Conjugarão eles o seu atendimento de necessidades individuais de saúde à permanente compreensão do perfil epidemiológico da população, exercendo competentemente 0 seu ofício técnico face às principais e comuns ocorrências presentes nos municípios interioranos.

No que se refere à manutenção da saúde, é real sua importância em diferentes atividades junto às diversas instituições e reconhecidos grupos de risco da população, agindo de forma articulada, porém independente dos poderes locais,

Refletindo particularmente sobre os 108 cursos superiores de enfermagem em funcionamento no país (dados de 1994), crê-se que estes não fogem à regra dos demais cursos da área de saúde. Embora preocupados com a formação generalista e ensinamentos típicos da saúde pública, os cursos de enfermagem têm o seu currículo desenvolvido majoritariamente na instituição hospitalar e voltados para a assistência especializada, repetindo a antiga fórmula imposta pelo sistema de saúde reinante nos grandes centros urbanos.

Todavia, está só em fase de implementação novo currículo mínimo. Um amplo e competente trabalho desenvolvido pela $A B E n$, indicando e possibilitando aos cursos a experimentação de currículos mais coerentes ao exercício de uma enfermagem necessária à preservação da vida das pessoas e coletividades pautada na ética e no exercício da cidadania.

Têm-se consciência do momento difícil vivido no país. Mudanças substanciais de ordem sócio-econômicas se apresentam sem discussões onde a população seja o centro das reflexões. O compromisso governamental, sem citar outros, como a educação e a saúde, neste país não tem sido promissor em seus resultados. É pública a pouca atenção e cortes de verbas. Os interessados administram o caos e a desesperança dos usuários destes dois sistemas.

No momento é vantajoso preservar as conquistas alcançadas. É fundamental apoiar e desenvolver as atividades que consolidam o poder municipal e a descentralização dos serviços, fortalecer os principios da Reforma Sanitária e a construção do SUS. Espera-se, portanto, da enfermagem brasileira a formação de enfermeiros lúcidos no exame do presente e empenhados na construção do futuro. 